\section{Assessment of runoff water quality for an integrated best management practice system in an agricultural watershed}

\author{
R.E. Lizotte, Jr. and M.A. Locke
}

\begin{abstract}
To better understand, implement, and integrate best management practices (BMPs) in agricultural watersheds, critical information on their effectiveness is required. A representative agricultural watershed, Beasley Lake, was used to compare runoff water quality draining through an integrated system of BMPs from row crop cultivated subdrainages as part of the national Conservation Effects Assessment Project (CEAP). From 2011 to 2014, runoff samples were collected across three subdrainages representing two integrated BMPs and three subdrainages representing row crop cultivation. Best management practice sites studied were two vegetated drainage ditches (east [EDV] and west [WDV]) that subsequently flowed into a vegetated sedimentation pond (SP). A suite of critical water quality parameters were assessed and included total suspended solids (TSS), total phosphorus (TP), total nitrogen (TN), nitrate-nitrogen $\left(\mathrm{NO}_{3}-\mathrm{N}\right)$, ammonium-nitrogen $\left(\mathrm{NH}_{4}-\mathrm{N}\right)$, and orthophosphate-phosphorus $\left(\mathrm{PO}_{4}-\mathrm{P}\right)$. During the four-year study period, integrated BMPs were effective at mitigating TSS runoff loads relative to row crop, but less effective at mitigating nutrient runoff loads. Runoff from WDV and SP were only moderately effective in mitigating nutrients in runoff with only TN and TP consistently reduced relative to row crop. Effectiveness of BMPs were primarily a result of the amount of area in tillage practices and crops planted relative to BMP within subdrainage basin area. Decreasing tillage:BMP and/or crop:BMP area ratios produced a subsequent decrease in runoff loads with the exception of $\mathrm{NH}_{4}-\mathrm{N}$ and $\mathrm{PO}_{4}-\mathrm{P}$.
\end{abstract}

Key words: lake watershed-nutrients - total suspended solids-vegetated ditchesvegetated sediment pond

\begin{abstract}
Challenges of the 21st century will encompass providing adequate food and textiles for an ever-increasing human population. For agriculture to continue to meet these growing needs, there will be increasing demand to efficiently maximize usage of arable land and associated large-scale agricultural practices. Such practices include mechanized soil tillage and the application of industrial chemical fertilizers and pesticides, all of which can impact water resources (Garnett 2013). A growing body of research over the last several years has shown that targeted watershed-scale implementation of cultural and/or structural conservation or best management practices (BMPs) by farmers and land managers can significantly reduce the transport of sediment, nutrients, and other pollutants from fields to vulnerable downstream water bodies in watersheds
\end{abstract}

To help address these research needs, the Conservation Effects Assessment Project (CEAP) was established in 2004. The CEAP program identified 14 agricultural watersheds to be studied in support of goals to identify and assess water quality benefits of various BMPs and their placement in these watersheds (Tomer and Locke 2011). Although CEAP has been successful in providing land managers and farmers with a better understanding of emerging BMPs and other technologies in the last decade, gaps remain in our understanding of the use and effectiveness of multiple integrated BMPs embedded in watershed-scale agricultural landscapes (Tomer et al. 2014). The purpose of the current study is to examine the effectiveness of two integrated BMPs in mitigating storm-driven surface runoff water quality. The study assessed integrated BMPs of vegetated drainage ditches (California and Mississippi Natural Resources Conservation Service [NRCS] practice 607A) combined with a sediment retention pond (NRCS practice 638) during a four-year monitoring period (2011 to 2014) in a CEAP watershed, Beasley Lake.

\section{Materials and Methods}

Study Site Description. The study watershed, Beasley Lake, is 625 ha $(1,544$ ac) located adjacent to the Big Sunflower River in Sunflower County, Mississippi, with approximately $54 \%$ of the land in row crop cultivation. Study subdrainage basin areas were established and delineated using methods described by Cullum et al. (2010). East vegetated drainage ditch (EDV) subdrainage basin is 81.5 ha $(201.4 \mathrm{ac})$ with 76.6 ha $(189.3 \mathrm{ac})$ in row crop, 2 ha $(4.9 \mathrm{ac})$ vegetated drainage ditch, and 3 ha $(7.4 \mathrm{ac})$ in vegetated buffer. West vegetated drainage ditch (WDV) subdrainage basin is 43.3 ha $(107 \mathrm{ac})$ with $42.3 \mathrm{ha}(104.5 \mathrm{ac})$ in row crop and 1 ha $(2.5 \mathrm{ac})$ vegetated drainage ditch. The vegetated sedimentation pond (SP) is 0.99 ha $(2.4 \mathrm{ac})$ and includes the combined subdrainage basins of both EDV and WVD for a total of 125.8 ha $(310.9 \mathrm{ac})$. Three row crop subdrainage basins are, from east to west, as follows: 2.8 ha (6.9 ac; RC1), 3.5 ha

Richard E. Lizotte, Jr. (corresponding author) is an ecologist and Martin A. Locke is a soil scientist at the Water Quality and Ecology Research Unit, National Sedimentation Laboratory, USDA Agricultural Research Service (ARS), Oxford, Mississippi. 
(8.6 ac; RC2), and 5.1 ha (12.6 ac; RC3), respectively (figure 1). Soils in Beasley Lake watershed are a mosaic of various soil types frequently occurring around fluvial lakes in alluvial river basins. Deposited soils primarily include Alligator, Bosket, Dowling, Dundee, Forestdale, and Sharkey soil series. Textures of these soils include sandy loam, silty loam, and clays. A more complete description is provided in Lizotte et al. (2017).

The EDV channel was approximately $1,000 \mathrm{~m}$ (0.62 mi) long, 5 to $15 \mathrm{~m}$ (16 to

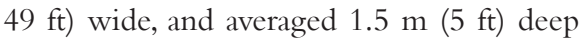
with a slope of $0.22 \mathrm{~cm} \mathrm{~km}^{-1}\left(0.14 \mathrm{in} \mathrm{mi}^{-1}\right)$. The EDV channel was vegetated naturally over the course of several years prior to the study period with a variety of miscellaneous grass species, including unknown grass species (Graminae); rice cutgrass (Leerisa oryzoides); and dicot species, including ragweed (Ambrosia sp.), smartweed (Polygonum sp.), and patches of alligator weed (Alternananthera philoxeroides). The WDV was approximately $250 \mathrm{~m}$ (0.16 mi) long, 2 to $7.5 \mathrm{~m} \mathrm{(6.5} \mathrm{to}$

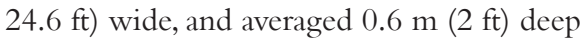
with a slope of $0.24 \mathrm{~cm} \mathrm{~km}^{-1}\left(0.15\right.$ in $\left.\mathrm{mi}^{-1}\right)$. The WDV channel was naturally vegetated with primarily rice cutgrass and patches of common cattail (Typha latifolia). The SP, implemented in 2010, was a modified design from USDA NRCS conservation practice standard Code 350. Typically a sediment basin designed by NRCS is longer than it is wide, and its length is sized to maximize settlement time, while overall dimensions are meant to reduce water velocities and increase hydraulic retention time (HRT). This varies based upon soil particle size designed to be captured. However, in Beasley Lake watershed, flow length for SP was constrained. As a result, the basin had to use as much width as could be managed, then use two separated detention cells within the basin in an attempt to maximize HRT and settlement time. The southern inflow detention cell was approximately $50 \mathrm{~m}$ (164 ft) long and $105 \mathrm{~m}$ (345 $\mathrm{ft})$ wide with a peak water depth of $2 \mathrm{~m}(6.5$ $\mathrm{ft}$ ). Four $0.56 \mathrm{~m}$ (22 in) diameter pipes with staggered elevations to slow water flow to the second detention cell connected both cells. The northern outflow detention cell was approximately $50 \mathrm{~m}$ (164 ft) long and $90 \mathrm{~m}(295 \mathrm{ft})$ wide with similar peak water depth of about $2.1 \mathrm{~m}$ (7 ft). Outflow from the northern detention cell into the lake was controlled by a $1.2 \mathrm{~m}(3.9 \mathrm{ft})$ riser and 0.9 $\mathrm{m}(2.9 \mathrm{ft})$ barrel with a $0.3 \mathrm{~m}(1 \mathrm{ft})$ diameter

\section{Figure 1}

Map of Beasley Lake watershed displaying locations of subdrainage runoff sampling sites: east vegetated drainage ditch (EDV), west vegetated drainage ditch (WDV), vegetated sedimentation pond (SP), and row-crop cultivation (RC 1 through 3), from 2011 to 2014. Arrows indicate water flow path in drainage ditches.

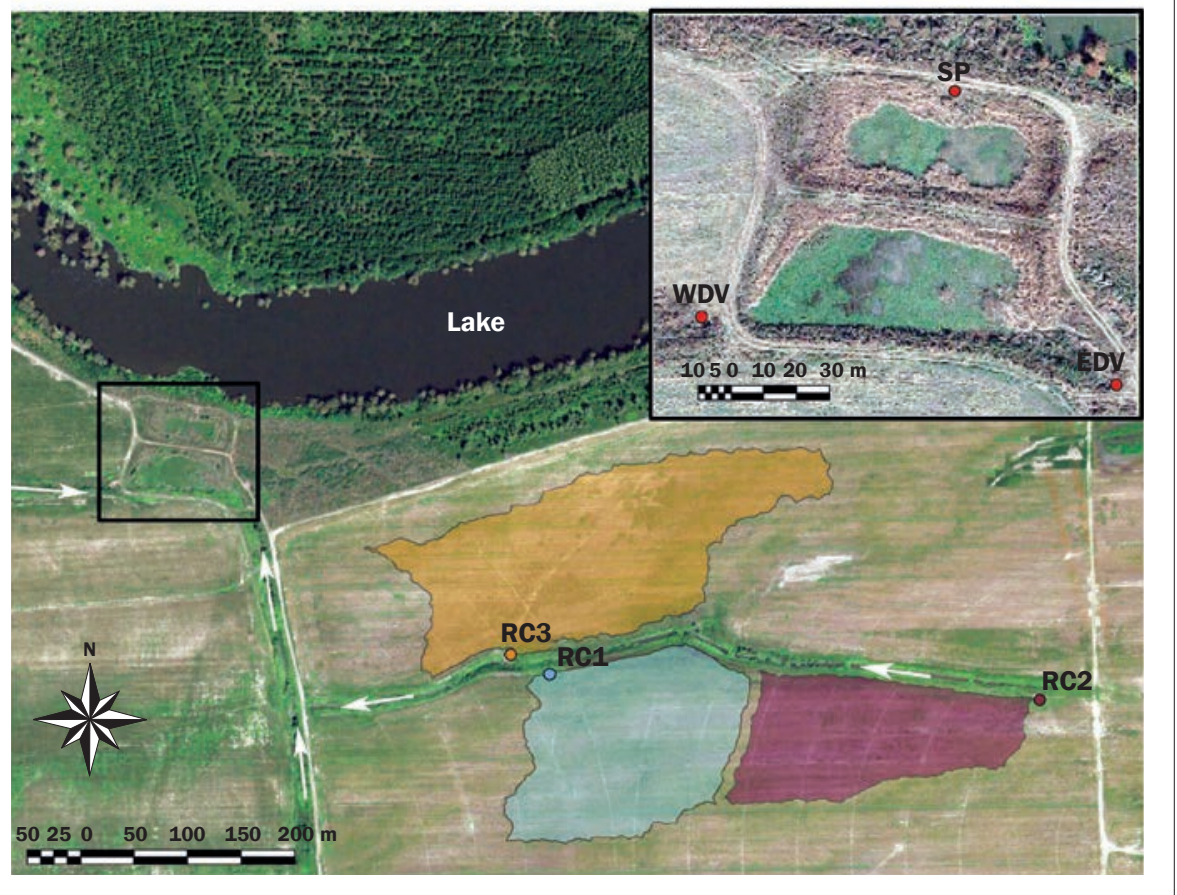

inlet pipe to riser to allow water drawdown. This limited the physical size, dimensions, and overall design of SP to fit the area the landowner was willing to provide (personal communication, Paul Rodrigue, USDA NRCS, 2009). During storm events, estimated median (25th to 75 th percentile) SP HRT was 35 (21 to 94) hours with some water flowing through the sediment basin in less than 12 hours in high-flow events. The SP was vegetated primarily with alligator weed, arrowhead (Sagittaria latifolia), and Alamo switchgrass (Panicum virgatum). Establishment of SP vegetative cover increased every year after implementation in 2010 from 41\%, $75 \%, 85 \%$, to $90 \%$ in $2011,2012,2013$, and 2014 , respectively. Soil management practices (tillage) and crop cultivation in row crop areas varied during the study years (table 1). Conventional tillage practices in the Delta include disking about $15 \mathrm{~cm}$ (5.9 in) in the fall after harvest, followed by subsoiling once (as needed when determined by the manager) and possible additional disking (disked twice) when needed to prepare plant beds for fall. In the spring, plant beds were reformed through harrowing, rolling, and/or rehipping as needed prior to planting (Yuan et al.2013). In 2011, the soil within the subdrainages was tilled using subsoiling and disking with rehipping prior to planting. Crops planted in 2011 were soybeans (Glycine max [L.] Merr.) and cotton (Gossypium hirsutum L.). For 2012, soils were disked twice, harrowed, and rehipped prior to planting when soybeans, corn (Zea mays L.), and winter wheat (Triticum aestivum L.) were cultivated. In 2013 and 2014, soil was disked and harrowed and planted in soybeans in all subdrainages.

Storm Water Sampling and Analysis. Storm events within the study watershed producing rainfall and surface runoff were measured and sampled as described by Cullum et al. (2010). Briefly, rainfall was measured using a $0.025 \mathrm{~mm}$ (0.001 in) tipping bucket rain gauge. At each subdrainage study site, surface storm water runoff was measured and sampled with an integrated Doppler area-velocity sensor measuring flow connected with a composite water sampler from ISCO (Teledyne ISCO, Lincoln, Nebraska). Flow sensors and storm water sampler inflow lines were mounted inside drainage culvert pipes at all sites. Storm water samplers were programmed to automatically collect composite storm water samples when surface runoff flow was detected. Within approximately 24 hours of storm water col- 
lection, samples were retrieved, preserved at $4^{\circ} \mathrm{C}\left(39.2^{\circ} \mathrm{F}\right)$ on wet ice, and transported to the National Sedimentation Laboratory in Oxford, Mississippi, for water quality analysis.

Physical and chemical water quality parameters were measured, and unfiltered samples were analyzed. Total suspended solids (TSS) were dried at $103^{\circ} \mathrm{C}$ to $105^{\circ} \mathrm{C}\left(217^{\circ} \mathrm{F}\right.$ to $\left.221^{\circ} \mathrm{F}\right)$ according to APHA (2005). Total phosphorus (TP: Lachat method 10-115-01-1-C), and total Kjeldahl nitrogen (TKN: Lachat method 10-107-06-2-E) were measured after digestion (sulfuric acid $\left[\mathrm{H}_{2} \mathrm{SO}_{4}\right]$ with mercuric oxide $[\mathrm{HgO}]$ and potassium sulfate $\left[\mathrm{K}_{2} \mathrm{SO}_{4}\right]$ ) followed by analysis using a Lachat QuickChem 8500 Series II auto analyzer (Lachat Instruments, Hach Company, Loveland, Colorado). Filtered $(0.45 \mu \mathrm{m})$ samples were analyzed for nitrate-nitrogen $\left(\mathrm{NO}_{3}-\mathrm{N}\right.$; Lachat method 10-107-06-1-J), nitrite-N ( $\mathrm{NO}_{2}-\mathrm{N}$; Lachat method 10-107-05-1-B), ammonium-N $\left(\mathrm{NH}_{4}-\mathrm{N}\right.$; Lachat method 10-107-04-1-C), and orthophosphate-phosphorus $\left(\mathrm{PO}_{4}-\mathrm{P}\right.$; Lachat method 10-115-01-1-A) also using a Lachat QuickChem 8500 Series II auto analyzer. Estimated total $\mathrm{N}$ (TN) was the sum of $\mathrm{NO}_{3}-\mathrm{N}, \mathrm{NO}_{2}-\mathrm{N}$, and TKN. Reported loads of each measured water quality constituent were calculated based on total discharge of each sampled storm event per unit area due to differences in subdrainage basin areas of the sample sites as previously described.

Data Analysis. Data were sorted by study subdrainage basin and year prior to analysis. Due to the well-documented nonparametric characteristics of water quality data (Burton and Pitt 2002), analyses were conducted with nonparametric statistical tests or ranked (median) load data were used when using parametric statistical tests (Conover and Iman 1981). Median values of each water quality constituent load for each subdrainage site were compared using a Kruskal-Wallis analysis of variance (ANOVA) on ranks with Dunn's multiple comparison test versus row crop sites as the positive control sites. Median data generated by subdrainage basin and year were used to assess associations of annual soil management practices and crop cultivation with water quality variables using multiple linear, linear, and nonlinear regression analyses during the four-year study period. Additional nonlinear regression analysis was conducted using raw data of nutrient constituents versus TSS to determine the relationship of TSS as a carrier of nutrient runoff loads. Classification and regression tree
(CART) analysis using automatic interaction detection with least squared loss method was conducted to assess change points (Stevenson et al. 2012; Haggard et al. 2013) when water quality variables (dependent variable) changed, which annual soil management practice(s) or crop cultivation (independent variable) was associated with that change, and the area ratio of soil management or crop to vegetated buffer. Classification and regression tree analysis used median data (as previously described for regression analysis) to generate proportional reduction in error (PRE) and improvement values (goodnessof-fit statistics comparable to multiple $r^{2}$ values). Stopping criteria for CART analysis were as follows: minimum split index value of 0.05 , minimum improvement in PRE of 0.05 , maximum allowed node number of 21 , and minimum allowed node count of five. Statistical significance $(\alpha)$ for ANOVA and regression analyses was set at $p \leq 0.05$ (Steel et al. 1997). All statistical analyses were conducted using SigmaStat (SigmaPlot v.12, Systat Software Inc., San Jose, California) or SYSTAT (SYSTAT v.13, Systat Software Inc., San Jose, California) statistical software.

\section{Results and Discussion}

Rainfall. On average, approximately 29 rainfall storm events were sampled annually during the four-year study period, ranging from 26 to 33 events per year (figure $2)$. Rainfall amounts during sampled storm events ranged from as little as $9 \mathrm{~mm}(0.35$ in) to as much as $130 \mathrm{~mm}$ (5.12 in), with most samples collected during storms $>12$ $\mathrm{mm}$ (about $0.5 \mathrm{in}$ ). During the study period, most rainfall storm events occurred during winter and spring prior to or just after crop planting, with fewer events during the drier part of the year in summer and fall during peak crop growth and harvest (figure 2). This pattern is typical of the Mississippi Delta region where about $75 \%$ of the annual rainfall occurs during the cold season and only about $25 \%$ occurs during the warm growing season (Sherman-Morris et al. 2012).

Runoff of Suspended Sediment and Nutrients. Suspended sediment and nutrient water quality storm runoff data for the different subdrainages are presented in figure 3 Median TSS runoff loads were $1.057 \mathrm{t} \mathrm{ha}^{-1}$ $\left(0.471 \mathrm{tn} \mathrm{ac}^{-1}\right), 0.108 \mathrm{tha}^{-1}\left(0.048 \mathrm{tn} \mathrm{ac}^{-1}\right)$, and $0.104 \mathrm{t} \mathrm{ha}^{-1}\left(0.047 \mathrm{tn} \mathrm{ac}^{-1}\right)$ at RC1 through RC3 and $0.097 \mathrm{t} \mathrm{ha}^{-1}\left(0.043 \mathrm{tn} \mathrm{ac}^{-1}\right), 0.035 \mathrm{t}$ $\mathrm{ha}^{-1}\left(0.015 \mathrm{tn} \mathrm{ac}^{-1}\right)$, and $0.024 \mathrm{t} \mathrm{ha}^{-1}(0.011 \mathrm{tn}$ $\mathrm{ac}^{-1}$ ) in EDV, WDV, and SP, respectively (figure 1 and 3a). Results of ANOVA on ranks analysis for TSS indicated significant decreases in median TSS loads relative to RC1 through RC3 for EDV, WDV, and SP subdrainage sites during the study (figure 3a). Significant median TSS load decreases ranged from 69\% in WDV (relative to RC2) to as much as 97\% in SP (relative to RC1). In general, SP and WDV had greater decreases in TSS loads than EDV, but TSS loads from all three sites were significantly reduced relative to RC1.

Decreases in nutrient runoff loads relative to all row crop sites were less consistent. Total $\mathrm{P}$ runoff loads transported from subdrainage basins during 2011 to 2014 were greatest at RC1 with a median TP load of $0.34 \mathrm{~kg} \mathrm{ha}^{-1}$ $\left(0.31 \mathrm{lb} \mathrm{ac}^{-1}\right)$, and lowest at SP and WDV with median loads of $0.05 \mathrm{~kg} \mathrm{ha}^{-1}(0.04 \mathrm{lb}$ $\left.\mathrm{ac}^{-1}\right)$ and $0.04 \mathrm{~kg} \mathrm{ha}^{-1}\left(0.03 \mathrm{lb} \mathrm{ac}^{-1}\right)$, respectively. Median TP runoff loads significantly decreased relative to RC1 at EDV, WDV, and SP at $84 \%, 90 \%$, and $87 \%$, respectively. Median TP runoff loads, while decreasing at EDV, WDV, and SP from $16 \%$ to $33 \%, 49 \%$ to $59 \%$, and $32 \%$ to $46 \%$, respectively, were not statistically significantly lower relative to $\mathrm{RC} 2$ or $\mathrm{RC} 3$, due, in part, to the wide range of TP runoff loads among storm events from 2011 to 2014 (figure 3b). Total P loads were strongly associated with TSS loads $\left(r^{2}\right.$ $=0.807)$, signifying that TSS is a significant carrier of this nutrient, accounting for more than $80 \%$ of the variation in TP loads across all sites (figure 4a).

Total N runoff loads during 2011 to 2014 exhibited similar patterns to TP loads. Median loads of TN in runoff were greatest at RC1 with $1.71 \mathrm{~kg} \mathrm{ha}^{-1}\left(1.52 \mathrm{lb} \mathrm{ac}^{-1}\right)$, followed by RC3 with $0.39 \mathrm{~kg} \mathrm{ha}^{-1}(0.34 \mathrm{lb}$ $\left.\mathrm{ac}^{-1}\right)$ and RC2 with $0.29 \mathrm{~kg} \mathrm{ha}^{-1}\left(0.26 \mathrm{lb} \mathrm{ac}^{-1}\right)$. Vegetated BMP sites produced median TN runoff loads at EDV,WDV, and SP of $0.25 \mathrm{~kg}$ $\mathrm{ha}^{-1}\left(0.22 \mathrm{lb} \mathrm{ac}^{-1}\right), 0.16 \mathrm{~kg} \mathrm{ha}^{-1}\left(0.14 \mathrm{lb} \mathrm{ac}^{-1}\right)$, and $0.19 \mathrm{~kg} \mathrm{ha}^{-1}\left(0.17 \mathrm{lb} \mathrm{ac}^{-1}\right)$, respectively. Statistically significant reductions in median TN runoff loads relative to row crop sites were observed for site RC1 only with significant decreases of $85 \%$ (EDV), 91\% (WDV), and $89 \%(\mathrm{SP})$. Relative to RC2 and RC3 loads, median TN loads were lower at EDV (13\% to $35 \%$ ), WDV ( $45 \%$ to $59 \%$ ), and SP ( $34 \%$ to $51 \%$ ), but, again, due to large variations in loads, these differences were not statistically significant (figure 3c). As with $\mathrm{TP}, \mathrm{TN}$ loads were also very strongly associated with TSS loads. Total suspended solids 


\section{Figure 2}

Storm event with measured rainfall and flow for (a) 2011, (b) 2012, (c) 2013, and (d) 2014 from subdrainage runoff sampling sites: east vegetated drainage ditch (EDV), west vegetated drainage ditch (WDV), vegetated sedimentation pond (SP), and row crop cultivation (RC).

(a)

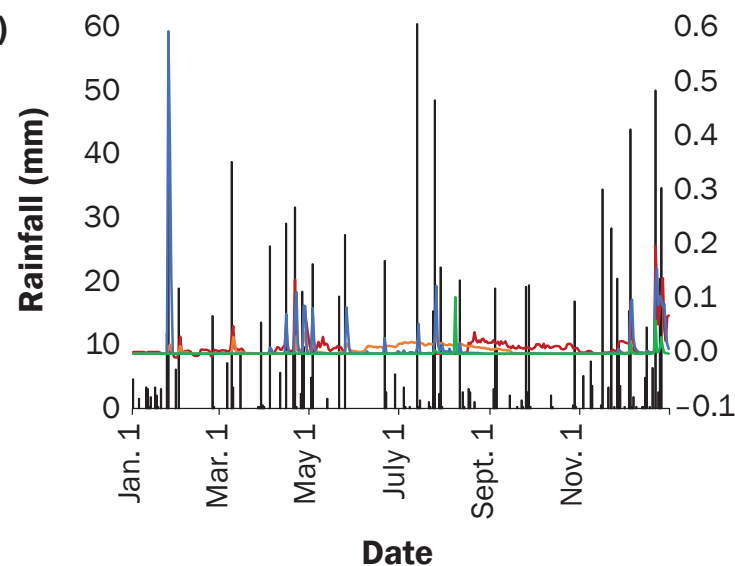

(c)

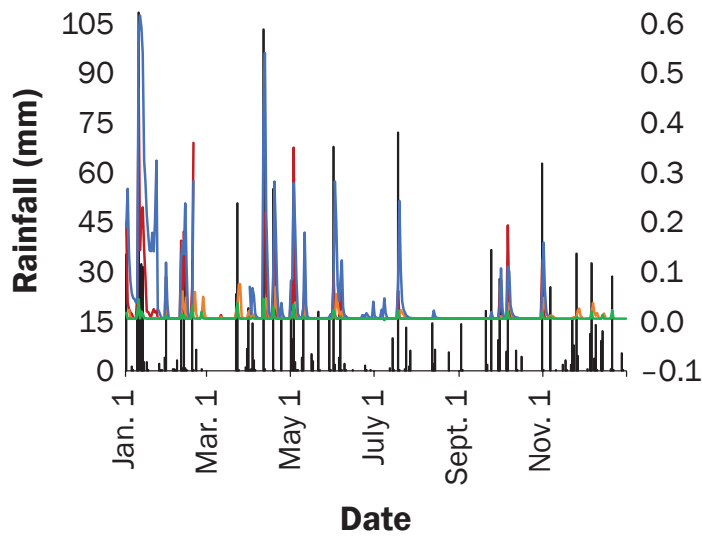

(b)

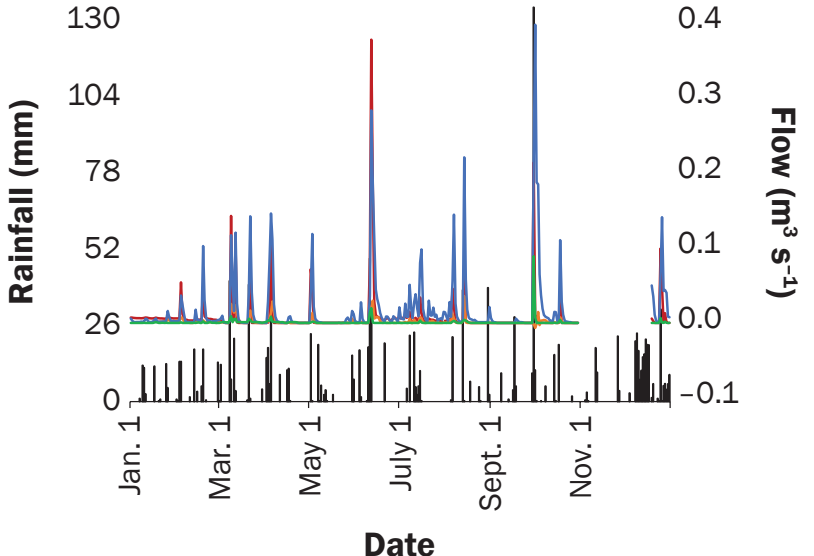

(d)

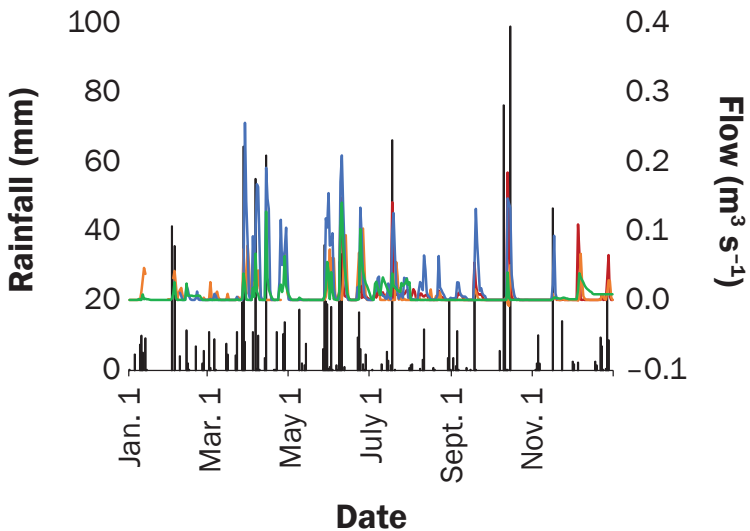

accounted for more than $76 \%$ of TN variation $\left(r^{2}=0.7669\right)$, indicating TSS is a carrier for the bulk of TN in runoff (figure $4 b$ ).

Storm event-generated soluble inorganic nutrient runoff loads measured from 2011 to 2014 exhibited more modest reductions in loads between row crop and vegetated runoff sites. Median $\mathrm{NO}_{3}-\mathrm{N}$ runoff loads during the study were greatest at RC1 with 0.19 $\mathrm{kg} \mathrm{ha}^{-1}\left(0.17 \mathrm{lb} \mathrm{ac} \mathrm{cos}^{-1}\right)$ and RC2 with 0.08 $\mathrm{kg} \mathrm{ha}{ }^{-1}\left(0.07 \mathrm{lb} \mathrm{ac}^{-1}\right)$. Median $\mathrm{NO}_{3}-\mathrm{N}$ loads $<0.05 \mathrm{~kg} \mathrm{ha}^{-1}\left(0.04 \mathrm{lb} \mathrm{ac}^{-1}\right)$ were measured at the remaining sites, with WDV and SP having the lowest loads of about $0.02 \mathrm{~kg} \mathrm{ha}^{-1}$ $\left(0.02 \mathrm{lb} \mathrm{ac}^{-1}\right)$. Nitrate-N storm runoff loads also showed significant reductions in median values relative to RC1 at EDV (76\%), WDV $(89 \%)$, and SP (87\%). Median $\mathrm{NO}_{3}-\mathrm{N}$ loads at RC2 and RC3 were more similar to EDV, WDV, and SP, and were not statistically sig- nificantly different (figure 3d). Nitrate-N loads were not as strongly associated with TSS loads as either TP or TN. Loads of TSS accounted for about $52 \%$ of $\mathrm{NO}_{3}-\mathrm{N}$ runoff load variation $\left(r^{2}=0.5215\right)$, indicating about half of the measured $\mathrm{NO}_{3}-\mathrm{N}$ load is carried with TSS runoff (figure 4c).

In contrast, median $\mathrm{NH}_{4}-\mathrm{N}$ runoff loads were the least influenced by vegetated runoff sites. Median $\mathrm{NH}_{4}-\mathrm{N}$ loads were highest at RC1 at $0.048 \mathrm{~kg} \mathrm{ha}^{-1}\left(0.043 \mathrm{lb} \mathrm{ac}^{-1}\right)$, but were only significantly decreased relative to WDV by about $85 \%$ at $0.007 \mathrm{~kg} \mathrm{ha}^{-1}(0.007$ $\mathrm{lb} \mathrm{ac}{ }^{-1}$. Median $\mathrm{NH}_{4}-\mathrm{N}$ runoff loads for RC2 and RC3 were 0.010 to $0.0126 \mathrm{~kg} \mathrm{ha}^{-1}$ (0.009 to $0.011 \mathrm{lb} \mathrm{ac}^{-1}$ ) while median EDV and SP $\mathrm{NH}_{4}-\mathrm{N}$ loads were 0.009 to 0.010 $\mathrm{kg} \mathrm{ha}^{-1}\left(0.008\right.$ to $\left.0.009 \mathrm{lb} \mathrm{ac}^{-1}\right)$. More similar median $\mathrm{NH}_{4}-\mathrm{N}$ load values and large variations in the range of loads for the remaining subdrainage sites (RC2 and RC3, EDV, and $\mathrm{SP})$ precluded significant differences from being observed (figure 3e). Ammonium-N loads were only weakly associated with TSS loads $\left(r^{2}=0.3725\right)$, signifying that TSS is not a significant carrier of this nutrient, and only accounted for about $37 \%$ of the variation in $\mathrm{NH}_{4}-\mathrm{N}$ loads across all sites (figure $4 \mathrm{~d}$ ).

Median $\mathrm{PO}_{4}-\mathrm{P}$ runoff loads showed an intermediate response compared to $\mathrm{NO}_{3}-\mathrm{N}$ and $\mathrm{NH}_{4}-\mathrm{N}$ to vegetated BMPs. As with TSS and all previous nutrients, site RC1 had the greatest median $\mathrm{PO}_{4}-\mathrm{P}$ load at $0.026 \mathrm{~kg} \mathrm{ha}^{-1}$ $\left(0.023 \mathrm{lb} \mathrm{ac}^{-1}\right)$, followed by RC3 at $0.018 \mathrm{~kg}$ $\mathrm{ha}^{-1}\left(0.016 \mathrm{lb} \mathrm{ac}^{-1}\right)$. Lowest median $\mathrm{PO}_{4}-\mathrm{P}$ runoff loads were observed at RC2, WDV, and SP with values of $0.005 \mathrm{~kg} \mathrm{ha}^{-1}(0.004 \mathrm{lb}$ $\left.\mathrm{ac}^{-1}\right), 0.007 \mathrm{~kg} \mathrm{ha}^{-1}\left(0.006 \mathrm{lb} \mathrm{ac}{ }^{-1}\right)$, and 0.010 $\mathrm{kg} \mathrm{ha}^{-1}\left(0.009 \mathrm{lb} \mathrm{ac}^{-1}\right)$, respectively (figure $\left.3 \mathrm{f}\right)$. Significant reductions in median $\mathrm{PO}_{4}-\mathrm{P}$ run- 


\section{Figure 3}

Box-whisker plots of (a) total suspended solids (TSS), (b) total phosphorus (TP), (c) total nitrogen (TN), (d) nitrate- $\mathrm{N}\left(\mathrm{NO}_{3}-\mathrm{N}\right)$, (e) ammonium-N $\left(\mathrm{NH}_{4}-\mathrm{N}\right)$, and ( $\left.\mathrm{f}\right)$ orthophosphate-P $\left(\mathrm{PO}_{4}-\mathrm{P}\right)$ loads during 2011 to 2014 from subdrainage runoff sampling sites: east vegetated drainage ditch (EDV), west vegetated drainage ditch (WDV), vegetated sedimentation pond (SP), and row crop cultivation (RC). A single asterisk (*) signifies significantly

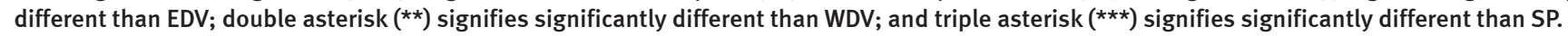
The $y$-axis is log scale.

(a)

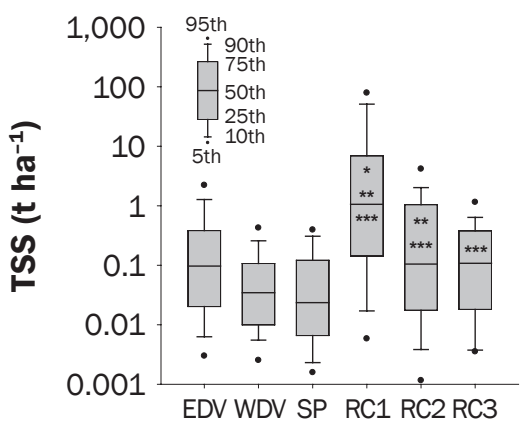

(d)

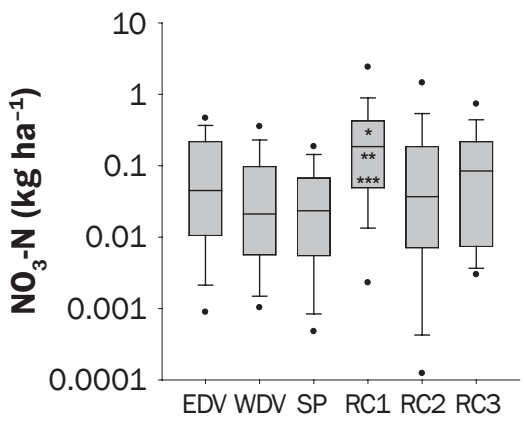

(b)

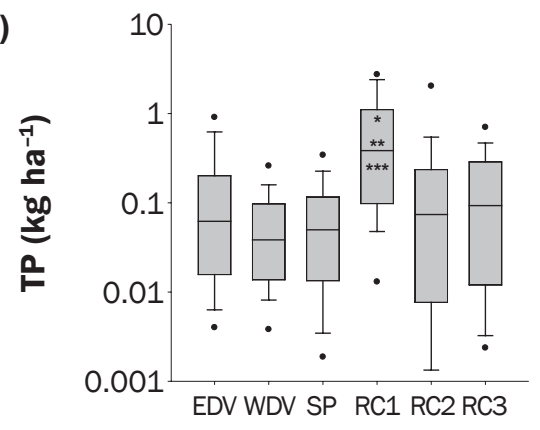

(e)

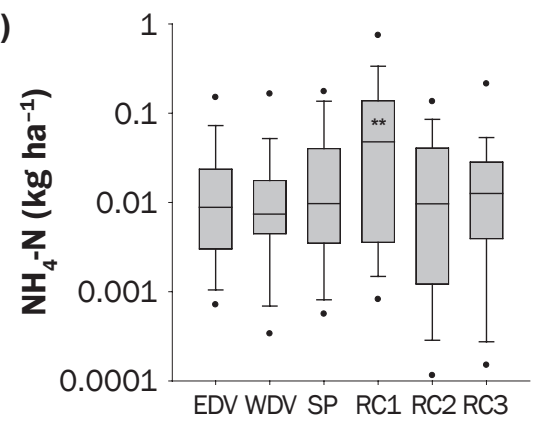

(c)

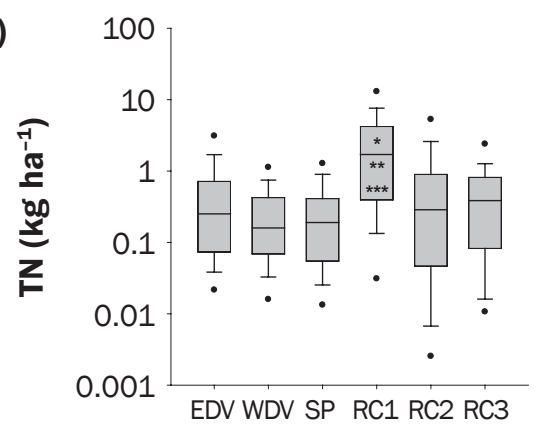

(f)

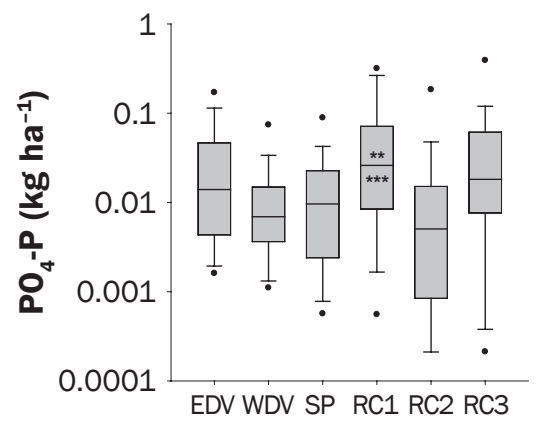

off loads relative to RC1 occurred for both WDV (73\%) and SP (63\%). Similar to $\mathrm{NH}_{4}^{-}$ $\mathrm{N}, \mathrm{PO}_{4}-\mathrm{P}$ loads were also weakly associated with TSS loads $\left(r^{2}=0.3743\right)$, with TSS accounting for only $37 \%$ of $\mathrm{PO}_{4}-\mathrm{P}$ variation (figure $4 \mathrm{e}$ ). The weaker associations with TSS indicate these more soluble components are much less influenced by TSS loads.

Regression Models. During the four-year study period, changes in soil management tillage practices and row crop cultivation patterns were observed (table 1). While implementation and establishment of the previously described BMPs occurred prior to the study period, several water quality parameters (TSS, TP, TN, and $\mathrm{NO}_{3}-\mathrm{N}$ ) responded to the integration of both BMPs relative to changes in land-management practices. This was evident in the use of linear and multiple linear regression models that showed sediment and nutrient parameters were influenced by the ratio of integrated land management:BMP ratios over the course of the study (table 2). Regression models of TSS showed the variable responded significantly to both soil management:BMP and row crop:BMP ratios. Specifically, intensive soil management combinations of disking and rehipping rows relative to BMP area explained $64.9 \%$ of TSS variation over four years $\left(r^{2}=0.649\right)$, while a combination of soybeans:BMP ratio following tillage explained $39.5 \%$ of TSS variation over four years $\left(r^{2}=0.395\right)$. Total P regressions indicating responses to multiple soil tillage:BMP ratio practices of double disking and harrowing explained $68.6 \%$ of the four-year TP variation $\left(r^{2}=0.686\right)$, while cotton:BMP and soybeans + cotton cultivation:BMP ratios following tillage explained $61.9 \%$ of TP variation $\left(r^{2}=0.619\right)$. For $\mathrm{N}$, $\mathrm{TN}$ regressions showing responses to soil tillage practices:BMP ratio via harrowing explained $36.8 \%$ of the four-year TN variation $\left(r^{2}=0.368\right)$, while corn cultivation:BMP ratio following tillage explained only $25.3 \%$ of TN variation $\left(r^{2}=0.253\right)$. Nitrate and $\mathrm{PO}_{4}-\mathrm{P}$ regressions showed these variables responded only to tillage practice and not row crop cultivation. Nitrate regression indicated a response to soil tillage practices:BMP ratios of a combination of disking, subsoiling, and double disking prior to crop planting that explained $30.5 \%$ of the $\mathrm{NO}_{3}$ variation $\left(r^{2}=0.305\right)$. No significant linear or multiple linear regression relationships were observed for either $\mathrm{NH}_{4}-\mathrm{N}$ or $\mathrm{PO}_{4}-\mathrm{P}$ with either tillage practices or cropping patterns (table 2).

Classification and regression tree analysis of water quality variables further elucidated patterns of responses by assessing the points of the four-year study when changes occurred (table 3). Models generated from CART analysis for TSS showed nearly identical PRE values, comparable to $r^{2}$ in regression models (Li et al. 2016), for both soil management practice:BMP ratio and row crop:BMP ratio (0.470 and 0.469 , respectively) across median values. Change points occurred from 2011 to 2012 when vegetated drainage ditches and SP combined to reduce TSS after disking and subsoiling followed by planting of soybeans and/or cotton. Reductions in TSS were apparent with soil management:BMP ratios from about 37 to 88 ha tillage $\mathrm{ha}^{-1} \mathrm{BMP}$ (91 to 217 ac tillage $2.5 \mathrm{ac}^{-1} \mathrm{BMP}$ ) and row crop:BMP ratios of about 37 ha soybean/ cotton cultivation $\mathrm{ha}^{-1}$ BMP (91 ac soybean/ cotton $\left.2.5 \mathrm{ac}^{-1} \mathrm{BMP}\right)$. Total P models showed PRE values of 0.443 and 0.258 for soil management:BMP and row crop:BMP ratios, respectively. Change points occurred from 


\section{Figure 4}

Linear regressions of total suspended solids (TSS) loads versus nutrient loads: (a) total phosphorus (TP), (b) total nitrogen (TN), (c) nitrate- $\mathrm{N}$ ( $\mathrm{NO}_{3}$ - $\mathrm{N}$ ), (d) ammonium- $-\mathrm{N}_{4}\left(\mathrm{NH}_{4}-\mathrm{N}\right)$, and (e) orthophosphate-P $\left(\mathrm{PO}_{4}-\mathrm{P}\right)$ during 2011 to 2014 from subdrainage runoff sampling sites. Both $y$-axis and $x$-axis are log scale.

(a)

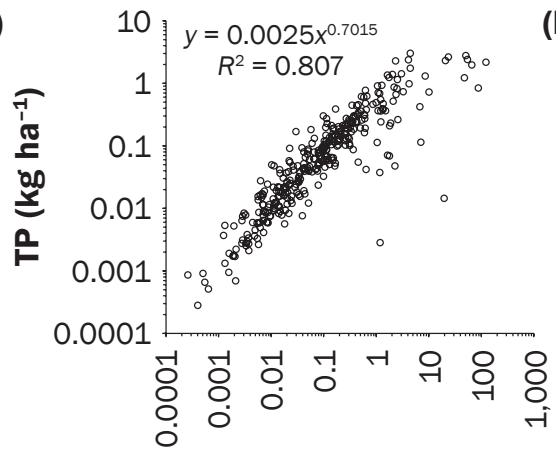

TSS (t ha-1) (b)

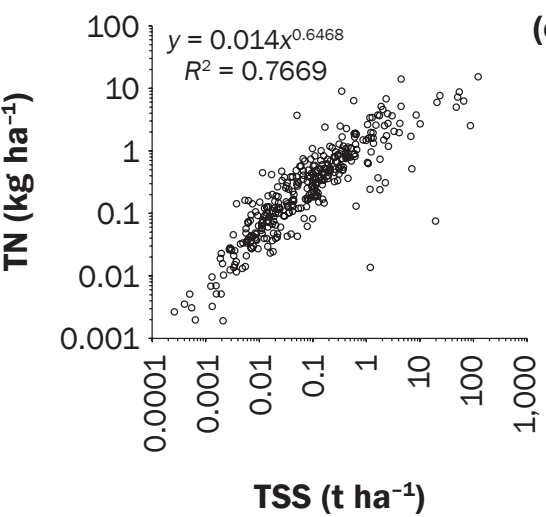

(c)

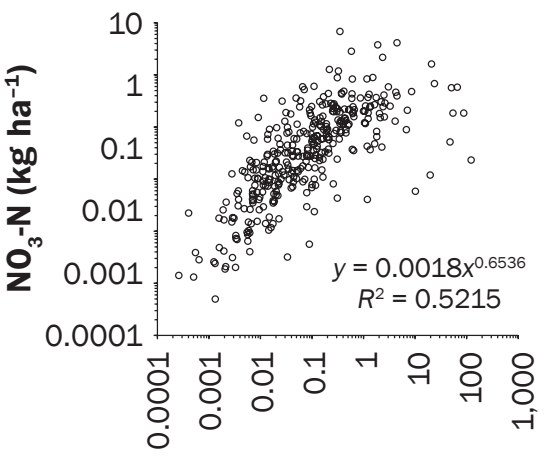

TSS (t ha-1) (d)

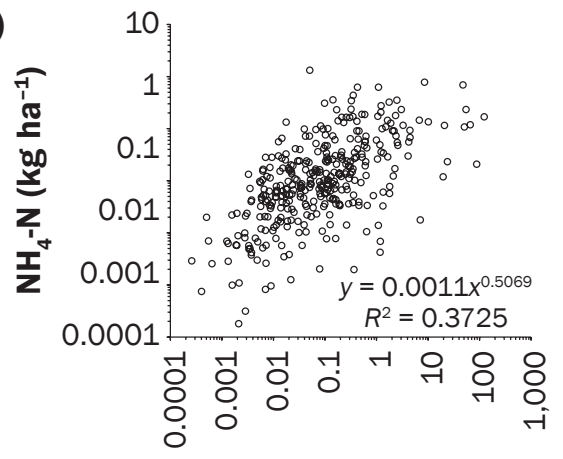

TSS (t ha-1) (e)

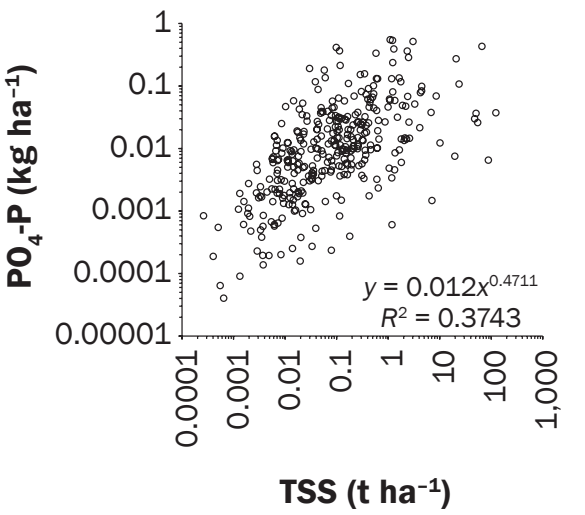

2011 to 2012 and indicated median TP loads were also reduced when drainage ditches and $\mathrm{SP}$ combined received runoff after combined tillage followed by planting of soybeans or cotton. Reductions in TP occurred with management:BMP ratios from about 44 to 132 ha for combinations of tillage ha ${ }^{-1} \mathrm{BMP}$ (109 to 326 ac tillage $2.5 \mathrm{ac}^{-1}$ BMP) and 37 ha soybean or cotton cultivation $\mathrm{ha}^{-1} \mathrm{BMP}$ (91 ac soybean or cotton cultivation $2.5 \mathrm{ac}^{-1}$ BMP). Total N CART models were much less robust, showing PRE values of 0.283 and 0.199 for soil management:BMP and row crop:BMP ratios, respectively. Change points for TN loads occurred in 2011 with EDV and SP reducing TN after tillage combination of disking, subsoiling, and double disking followed by planting of soybeans or cotton. Limited TN reductions were observed with soil management:BMP ratios of about 74 ha tillage $\mathrm{ha}^{-1}$ BMP (183 ac tillage $2.5 \mathrm{ac}^{-1}$ BMP) and about 37 ha row crop ha ${ }^{-1}$ BMP (91 ac row crop $2.5^{-1}$ ac BMP). Comparable to regression models, $\mathrm{NO}_{3}-\mathrm{N}$ CART models showed PRE values of 0.456 and 0.248 for soil management:BMP and row crop:BMP ratios, respectively. Nitrate- $\mathrm{N}$ change points also occurred in 2011 with vegetated ditches and $\mathrm{SP}$ reducing $\mathrm{NO}_{3}$ under combined tillage practices of disking, subsoiling, and double disking and after soybean and cotton planting. Nitrate- $\mathrm{N}$ reductions occurred with a soil management:BMP ratio of about 74 ha tillage $\mathrm{ha}^{-1}$ BMP (183 ac tillage 2.5 $\mathrm{ac}^{-1} \mathrm{BMP}$ ) and a crop:BMP ratio of about 37 ha soybean and cotton $\mathrm{ha}^{-1}$ BMP (91 ac soybean and cotton $\left.2.5 \mathrm{ac}^{-1} \mathrm{BMP}\right)$. In contrast to regression modelling, $\mathrm{NH}_{4}-\mathrm{N}$ produced a moderately robust CART model for soil management practices with a PRE value of 0.320 . Ammonium-N change point occurred in 2013 when $\mathrm{NH}_{4}-\mathrm{N}$ runoff loads decreased after harrowing. Ammonium decreases were observed with a soil management:BMP ratio of about 29 ha harrowing $\mathrm{ha}^{-1}$ BMP (73 ac harrowing $2.5 \mathrm{ac}^{-1} \mathrm{BMP}$ ).
For $\mathrm{PO}_{4}-\mathrm{P}$, poor robustness in CART models produced PRE values $<0.2$ (0.134 for soil management and 0.187 for row crop), which prevented any reliable change point determinations (table 3), and coincided with the lack of regression models.

Comparison of Nutrient Runoff in Midwest and Mississippi River Basin Watersheds. Beasley Lake watershed runoff nutrient concentrations varied considerably for both $\mathrm{P}$ and $\mathrm{N}$ (table 4). Concentrations of TP and $\mathrm{PO}_{4}$ ranged from $<0.01$ to 5.27 $\mathrm{mg} \mathrm{L} \mathrm{L}^{-1}$, and while the lower range of runoff concentrations were comparable with other CEAP watersheds in Indiana and Iowa (Smith et al. 2008; Tomer et al. 2008), the upper range of TP was much higher (table 4). Runoff concentrations of $\mathrm{NO}_{3}$ and $\mathrm{NH}_{4}$ in Beasley ranged from $<0.01$ to $21.9 \mathrm{mg} \mathrm{L}^{-1}$ and $<0.01$ to $13.1 \mathrm{mg} \mathrm{L}^{-1}$, respectively, and were comparable with higher range of runoff concentrations measured in a tile-drain Corn Belt watershed in Iowa (Tomer et al. 2008), 


\section{Table 1}

Area (ha) of soil management tillage practices and row-crop cultivation in subdrainage basins, east vegetated drainage ditch (EDV), west vegetated drainage ditch (WDV), and row-crop cultivation (RC) in Beasley Lake watershed from 2011 to 2014.

\begin{tabular}{|c|c|c|c|c|}
\hline Variable & 2011 & 2012 & 2013 & 2014 \\
\hline \multicolumn{5}{|l|}{ Soil management } \\
\hline \multicolumn{5}{|l|}{ EDV } \\
\hline Disking & 74 & 0 & 74 & 74 \\
\hline Subsoiling & 74 & 0 & 0 & 0 \\
\hline Disking twice & 0 & 74 & 0 & 0 \\
\hline Harrowing & 0 & 0 & 74 & 74 \\
\hline Rolling & 0 & 0 & 0 & 0 \\
\hline Rehipping & 74 & 0 & 0 & 0 \\
\hline \multicolumn{5}{|l|}{ WDV } \\
\hline Disking & 42 & 34 & 42 & 42 \\
\hline Subsoiling & 42 & 0 & 0 & 0 \\
\hline Disking twice & 0 & 8 & 0 & 0 \\
\hline Harrowing & 0 & 13 & 42 & 42 \\
\hline Rolling & 0 & 21 & 0 & 0 \\
\hline Rehipping & 42 & 21 & 0 & 0 \\
\hline \multicolumn{5}{|l|}{$\mathrm{RC}$} \\
\hline Disking & 11 & 0 & 11 & 11 \\
\hline Subsoiling & 11 & 0 & 0 & 0 \\
\hline Disking twice & 0 & 11 & 0 & 0 \\
\hline Harrowing & 0 & 0 & 11 & 11 \\
\hline Rolling & 0 & 0 & 0 & 0 \\
\hline Rehipping & 11 & 0 & 0 & 0 \\
\hline \multicolumn{5}{|l|}{ Row crop } \\
\hline \multicolumn{5}{|l|}{ EDV } \\
\hline Soybeans & 56 & 74 & 74 & 74 \\
\hline Cotton & 19 & 0 & 0 & 0 \\
\hline Corn & 0 & 0 & 0 & 0 \\
\hline Wheat & 0 & 0 & 0 & 0 \\
\hline \multicolumn{5}{|l|}{ WDV } \\
\hline Soybeans & 13 & 21 & 42 & 42 \\
\hline Cotton & 29 & 0 & 0 & 0 \\
\hline Corn & 0 & 21 & 0 & 0 \\
\hline Wheat & 0 & 13 & 42 & 42 \\
\hline \multicolumn{5}{|l|}{$\mathrm{RC}$} \\
\hline Soybeans & 7 & 11 & 11 & 11 \\
\hline Cotton & 4 & 0 & 0 & 0 \\
\hline Corn & 0 & 0 & 0 & 0 \\
\hline Wheat & 0 & 0 & 0 & 0 \\
\hline
\end{tabular}

but not those in Indiana or Missouri (Smith et al. 2008; Lerch et al. 2015). Similarly, Beasley TN runoff concentrations broadly ranged from 0.35 to $36.7 \mathrm{mg} \mathrm{L}^{-1}$. However, comparisons of TN concentrations in Beasley to other CEAP watersheds is limited as TN concentrations were not reported in Midwest and Mississippi River Basin watersheds (table 4).

Comparisons of nutrient loads across watersheds in the Midwest and Mississippi
River Basin were similar to those for concentrations, and included CEAP watersheds in Indiana, Iowa, Missouri, and Ohio (table 4). Loads of $\mathrm{TP}$ and $\mathrm{PO}_{4}$ in Beasley were comparable to those in Indiana and Missouri (Smith et al. 2008; Lerch et al. 2015) where the upper range of TP and $\mathrm{PO}_{4}$ loads were greater than $2.2 \mathrm{~kg} \mathrm{ha}^{-1}\left(2 \mathrm{lb} \mathrm{ac}^{-1}\right)$ and 0.55 $\mathrm{kg} \mathrm{ha}^{-1}\left(0.49 \mathrm{lb} \mathrm{ac}^{-1}\right)$, respectively (table 4). In contrast, $\mathrm{NO}_{3}$ and $\mathrm{NH}_{4}$ loads in Beasley were more similar to those measured in
Missouri and Ohio (Lerch et al. 2015; King et al. 2008) and much less than those of the tile-drain Corn Belt watersheds in Indiana and Iowa where the upper range of $\mathrm{NO}_{3}$ loads were $>19.2 \mathrm{~kg} \mathrm{ha}^{-1}\left(>17.1 \mathrm{lb} \mathrm{ac}^{-1}\right)^{3}$ (table 4). Comparisons of TN loads was limited to only those reported in Ohio by King et al. (2008) ranging from $<0.01$ to $13.8 \mathrm{~kg}$ $\mathrm{ha}^{-1}\left(<0.01\right.$ to $\left.12.3 \mathrm{lb} \mathrm{ac}^{-1}\right)$ and were comparable with the range of loads observed in Beasley (table 4).

Effectiveness of Integrated Best Management Practices. Results of this study showed that vegetated drainage ditches and SP integrated together was effective at mitigating TSS. While few studies have measured the effectiveness of vegetated drainage ditches in reducing TSS in runoff (Moore et al. 2010; Bulc et al. 2011), the underlying principal of increased vegetation decreasing water velocity and increasing sedimentation of TSS is well described (Moore et al. 2010). As such, vegetated drainage ditches behave more as low-lying vegetated filter strips, and observed decreases in percentage TSS loads were comparable with those of numerous studies showing that vegetated filters are very effective at trapping sediment (Liu et al. 2008). Similarly, research on the efficacy of sediment basins trapping TSS has been well established (Cooper and Knight 1990; Madaras and Jarrett 2000; Verstraeten and Poesen 2001; Bidelspach et al. 2004; McLaughlin et al. 2009), but is highly dependent on sediment particle size and HRT (Madaras and Jarrett 2000; Bidelspach et al. 2004). In the current study, while SP was also vegetated, HRT of SP was typically between one and four days, which limited the efficiency of this BMP. However, combining both vegetated drainage ditches and SP could potentially decrease TSS loads by $\geq 90 \%$ (figure 3a). Further, the results of the CART analysis indicate that only a small percentage of area, approximately $1 \%$ to $5 \%$ of the landscape, is necessary to establish enough vegetated buffer in existing drainage conduits to produce significant reductions in TSS, and that these benefits would be greatest with the most intensive tillage practices such as subsoiling and multiple disking (Yuan et al. 2009) (table 3). Such integrated BMPs are critically important in mitigating TSS runoff loads from highly erodible soils such as those occurring in the lower Mississippi Alluvial Plain. Limiting or even eliminating TSS runoff from reaching receiving water 


\section{Table 2}

Linear and multiple linear regression equations $(n=16)$ and coefficients of determination $\left(r^{2}\right)$ computed using median total suspended solids (TSS), total phosphorus (TP), total nitrogen (TN), nitrate $\left(\mathrm{NO}_{3}\right)$, ammonium $\left(\mathrm{NH}_{4}\right)$, and soluble reactive phosphorus $(\mathrm{PO})$ in runoff as dependent variables (y) versus area ratio of soil management practices: disking (D), subsoiling (SS), disking twice (D2), harrowing (HA), rolling (RL), and rehipping (RH) to best management practices (BMP); and area ratio of row crop cultivation: soybeans, cotton, and corn to BMP as independent variables ( $x$ ) from 2011 to 2014 .

\begin{tabular}{|c|c|c|c|c|c|}
\hline$y$ & $x_{1}$ & $x_{2}$ & Equation & $r^{2}$ & $p$-value \\
\hline \multicolumn{6}{|c|}{ Soil management } \\
\hline TSS & D:BMP & $\mathrm{RH}: \mathrm{BMP}$ & $y=36.825+\left(1.517 x_{1}\right)-\left(1.215 x_{2}\right)$ & 0.649 & 0.001 \\
\hline TP & D2:BMP & HA:BMP & $y=0.0441+\left(0.000521 x_{1}\right)+\left(0.000633 x_{2}\right)$ & 0.686 & $<0.001$ \\
\hline TN & HA:BMP & & $y=0.239+\left(0.00207 x_{1}\right)$ & 0.368 & 0.013 \\
\hline $\mathrm{NO}_{3}-\mathrm{N}$ & $D+S S+D 2: B M P$ & & $\log _{10}(y)=-2.456+\left[0.57 \log _{10}\left(x_{1}\right)\right]$ & 0.305 & 0.027 \\
\hline $\mathrm{NH}_{4}-\mathrm{N}$ & None & & & & \\
\hline TSS & Soybeans:BMP & & $\log _{10}(y)=1.457+\left(0.00462 x_{1}\right)$ & 0.395 & 0.009 \\
\hline TP & Cotton:BMP & Soybeans + cotton:BMP & $y=0.0463-\left(0.00147 x_{1}\right)+\left(0.000561 x_{2}\right)$ & 0.619 & 0.002 \\
\hline TN & Corn:BMP & & $\log _{10}(y)=-0.551-\left(0.0299 x_{1}\right)$ & 0.253 & 0.047 \\
\hline $\mathrm{NO}_{3}-\mathrm{N}$ & None & & & & \\
\hline $\mathrm{NH}_{4}-\mathrm{N}$ & None & & & & \\
\hline
\end{tabular}

\section{Table 3}

Classification and regression tree (CART) analysis $(n=16)$ with node, mean, standard deviation (SD), and proportional reduction in error (PRE) for total suspended solids (TSS), total phosphorus (TP), total nitrogen (TN), nitrate $\left(\mathrm{NO}_{3}\right)$, ammonium $\left(\mathrm{NH}_{4}\right)$, and soluble reactive phosphorus (PO $)$ loads in runoff as dependent variables versus area ratio of vegetated buffer to soil management tillage practices: disking (D), subsoiling (SS), disking twice (D2), harrowing $(H A)$, rolling (RL), and rehipping (RH); and area ratio of vegetated buffer to row crop cultivation: soybeans, cotton, and corn as independent variables from 2011 to 2014 .

\begin{tabular}{|c|c|c|c|c|c|c|c|}
\hline \multirow[b]{2}{*}{ Variable } & \multirow[b]{2}{*}{ Node } & \multirow[b]{2}{*}{ Mean } & \multirow[b]{2}{*}{ SD } & \multicolumn{4}{|c|}{ Soil management or row crop } \\
\hline & & & & Type & Change point & PRE & Improve \\
\hline & & & & Soil management & & & \\
\hline \multirow[t]{2}{*}{ TSS } & 1 & 1.77 * & 0.51 & $D+S S+D 2: B M P$ & 87.80 & 0.326 & 0.326 \\
\hline & 2 & $1.58 *$ & 0.47 & $\mathrm{D}: \mathrm{BMP}$ & 36.94 & 0.470 & 0.144 \\
\hline \multirow[t]{2}{*}{ TP } & 1 & 0.08 & 0.05 & All tillage:BMP & 131.71 & 0.371 & 0.371 \\
\hline & 2 & 0.06 & 0.03 & $D+S S+D 2: B M P$ & 43.90 & 0.443 & 0.073 \\
\hline TN & 1 & 0.32 & 0.22 & $D+S S+D 2: B M P$ & 73.88 & 0.283 & 0.283 \\
\hline $\mathrm{NO}_{3}-\mathrm{N}$ & 1 & $-1.42 *$ & 0.37 & $D+S S+D 2: B M P$ & 73.88 & 0.456 & 0.456 \\
\hline $\mathrm{NH}_{4}-\mathrm{N}$ & 1 & $-2.01 *$ & 0.34 & HA:BMP & 29.38 & 0.320 & 0.320 \\
\hline \multirow[t]{2}{*}{$\mathrm{PO}_{4}-\mathrm{P}$} & 1 & 0.01 & 0.02 & $\mathrm{D}+\mathrm{SS}+\mathrm{D} 2: \mathrm{BMP}$ & 73.88 & 0.134 & 0.134 \\
\hline & & & & Row-crop & & & \\
\hline TSS & 1 & $1.77 *$ & 0.51 & Soybean + cotton:BMP & 36.94 & 0.469 & 0.469 \\
\hline TP & 1 & $-1.21 *$ & 0.32 & Soybean + cotton:BMP & 36.94 & 0.258 & 0.258 \\
\hline TN & 1 & $0.60 *$ & 0.33 & Soybean + cotton:BMP & 36.94 & 0.199 & 0.199 \\
\hline $\mathrm{NO}_{3}-\mathrm{N}$ & 1 & $-1.42 *$ & 0.37 & Soybean + cotton:BMP & 36.94 & 0.248 & 0.248 \\
\hline $\mathrm{NH}_{4}-\mathrm{N}$ & 1 & 0.01 & 0.02 & Soybean + cotton:BMP & 36.94 & 0.094 & 0.094 \\
\hline \multirow[t]{2}{*}{$\mathrm{PO}_{4}^{-}-\mathrm{P}$} & 1 & $-2.02 *$ & 0.37 & Soybean + cotton:BMP & 36.94 & 0.063 & 0.063 \\
\hline & 3 & $-1.96 *$ & 0.39 & Soybean:BMP & 43.90 & 0.187 & 0.124 \\
\hline
\end{tabular}

* $\log _{10}$ transformed.

bodies such as lakes and rivers greatly reduces the degradation of ecosystems services such as primary production and fisheries in these aquatic systems (Bilotta and Brazier 2008). We can view the integration of vegetated drainage ditches and SP as one large vegetated filter or grassed waterway that intercepts and filters sediment-laden runoff. Importantly, these types of systems can be readily adapted to existing structures in agricultural landscapes, with SP being the most significant investment. Further reductions in TSS $>95 \%$ could potentially be achieved, but would likely include changes in soil manage- ment from conventional tillage to no-tillage practices (Helmers et al. 2012)

In contrast to TSS, nutrients such as TP, $\mathrm{TN}$, and $\mathrm{NO}_{3}-\mathrm{N}$ showed less consistent responses to the BMPs studied. For vegetated drainage ditches, our results were consistent with other studies indicating that nutrient 


\section{Table 4}

Range of nutrient concentrations and loads as total phosphorus (TP), total nitrogen (TN), nitrate ( $\mathrm{NO}_{3}$ ), ammonium (NH), and soluble reactive phosphorus ( $\mathrm{PO}_{4}$ ) for agricultural Conservation Effects Assessment Program (CEAP) watersheds in the Midwest and Mississippi River Basin.

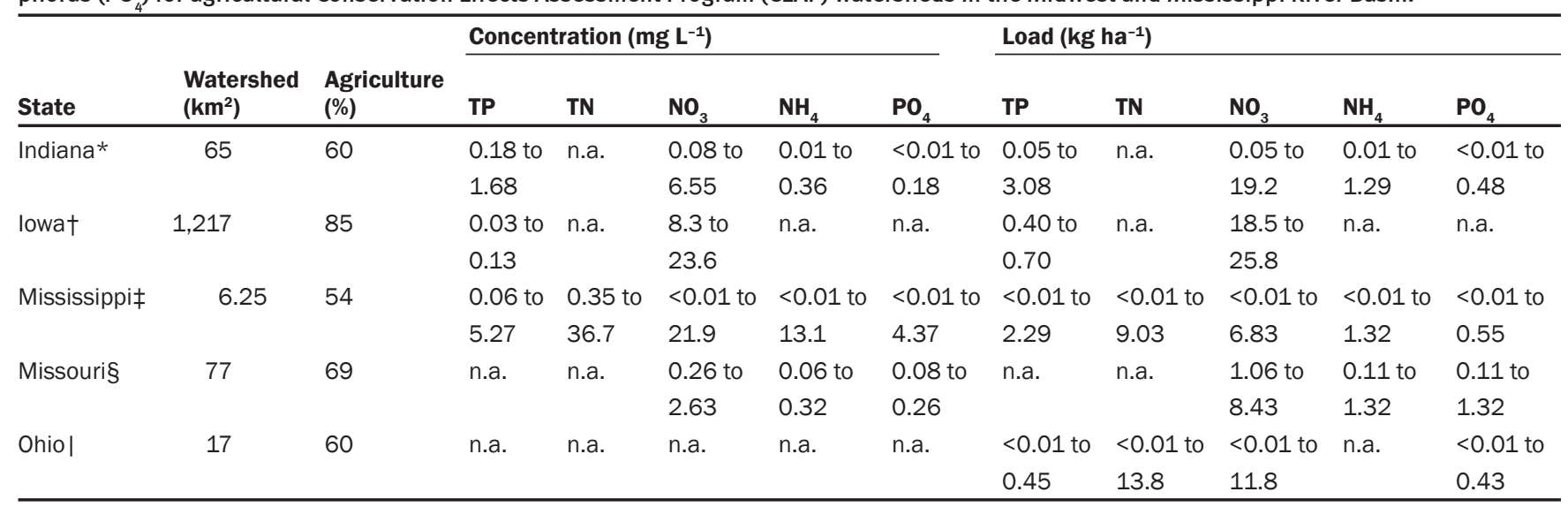

Note: n.a. = data not available for this constituent.

*Smith et al. (2008); data reported as flow-weighted means.

†Tomer et al. (2008); concentration data reported as means, load data reported as mean $\mathrm{kg} \mathrm{ha}^{-1} \mathrm{y}^{-1}$.

$\neq$ Current study.

$\S$ Lerch et al. (2015).

| King et al. (2008).

reductions in these systems are more complex (Moore et al. 2010; Kröger et al. 2011; Pierobon et al. 2013) and can be influenced by vegetation presence or absence, type of vegetation, HRT, and time of year (Kröger et al. 2007, 2011; Moore et al. 2010; Moore and Kröger 2011; Tyler et al. 2012). One aspect that has not been well-addressed at this scale is the influence of soil management tillage practices on total nutrients. In a study by Moore et al. (2010), the researchers simulated a storm runoff event that incorporated TSS, TP, and TN, and observed decreases in all three constituents in vegetated drainage ditches. In the present study, TP, TN, and $\mathrm{NO}_{3}-\mathrm{N}$ loads in runoff were observed to be significantly reduced with vegetated BMPs during periods of less intensive tillage practices and, consequently, lower TSS loads. This relationship was further elucidated in regression and CART analyses. These results indicate that during periods of more intensive tillage, mitigation of TSS could also coincide with significant mitigation of $\mathrm{TP}, \mathrm{TN}$, and $\mathrm{NO}_{3}-\mathrm{N}$ as runoff is directed through vegetated drainage ditches and SP integrated together. Furthermore, these integrated BMPs would encompass only a small percentage of area, approximately $1 \%$ to $5 \%$ of the landscape, to effectively mitigate TSS, $\mathrm{TP}, \mathrm{TN}$, and $\mathrm{NO}_{3}-\mathrm{N}$ when more intensive tillage practices are implemented on the agricultural landscape. For soluble nutrients such as $\mathrm{NH}_{4}-\mathrm{N}$ and $\mathrm{PO}_{4}-\mathrm{P}$, neither vegetated drainage ditches or SP, in isolation or combined, were highly effective at mitigation. Similarly, Moore et al. (2010) showed that vegetated drainage ditches weren't significantly better at reducing soluble nutrients than nonvegetated ditches. While vegetated BMPs such as drainage ditches and SP have been shown to reduce soluble nutrients during certain times of the year or under stable hydraulic conditions (Cooper and Knight 1990; Palmer-Felgate et al. 2011; Pierobon et al. 2013), further research indicated that nutrients can be exported from these vegetated systems during the nongrowing season (Kröger et al. 2007; Palmer-Felgate et al. 2011). This could explain why the present study observed more similar median load values in conjunction with large variations in soluble nutrients across the study sites. Nonvegetated conservation practices that could potentially decrease soluble nutrient loads in runoff would include improved fertilizer application management such as increased incorporation (injection into soil) to minimize runoff loss (Lerch et al. 2015). Also, practices that increase HRT within drainage ditches such as low-grade weirs were shown to improve the mitigation capacity of soluble N and P (Kröger et al. 2011). Such additional practices, while requiring more management from the farmer, would require no additional area be set aside as would be needed for additional buffers.

\section{Summary and Conclusions}

The current study provides a better understanding of the use and role of integrating BMPs in mitigating agriculturally sourced pollutants in storm runoff under varying management practices. Loads of TSS, TP,TN, and $\mathrm{NO}_{3}-\mathrm{N}$ in runoff were reduced with integrated vegetated drainage ditches and SP under intensive tillage practices such as multiple disking and subsoiling. However, reductions in nutrients were not as apparent under less intensive tillage practices and soluble nutrients, and in particular, did not seem to be mitigated by the vegetation. Implementation and integration of such BMPs utilize easily modified (i.e., naturally vegetated) existing drainage structures found in many agricultural landscapes with smallscale vegetated sediment treatment ponds to significantly improve water quality while minimizing monetary costs and arable land needed by farmers.

\section{Acknowledgements}

The authors would like to thank Calvin Vick, an agricultural research science technician, and Tim Sullivan, a physical science technician, both with the USDA Agricultural Research Service (ARS) National Sedimentation Laboratory in Oxford, Mississippi, for site set-up, maintenance, and sample collection; Lisa Brooks, a biological science technician, and 
James Hill, a chemist, both with the USDA ARS National Sedimentation Laboratory in Oxford, Mississippi, for laboratory water quality chemical analysis.

\section{References}

APHA (American Public Health Association). 2005. Standard Methods for the Examination of Water and Wastewater, 21st edition. Washington, DC: American Public Health Association, American Water Works Association, and Water Environment Federation.

Bidelspach, D.A., A.R. Jarett, and B.T. Vaughan. 2004. Influence of increasing the delay time between the inflow and outflow hydrographs of a sediment basin. Transactions of the American Society of Agricultural Engineers 47:439-444.

Bilotta, G.S., and R.E. Brazier. 2008. Understanding the influence of suspended solids on water quality and aquatic biota. Water Research 42:2849-2861.

Bulc, T.G., A.K. Klemenčič, and J. Razinger. 2011. Vegetated ditches for treatment of surface water with highly fluctuating water regime. Water Science and Technology 63:2353-2359.

Burton, G.A., and R.E. Pitt. 2002. Stormwater Effects Handbook: A Toolbox for Watershed Managers, Scientists, and Engineers, p. 911. Washington, DC: Lewis Publishers.

Conover, W.J., and R.L. Iman. 1981. Rank transformations as a bridge between parametric and nonparametric statistics. The American Statistician 35:124-129.

Cooper, C.M., and S.S. Knight. 1990. Nutrient trapping efficiency of a small sediment detention reservoir. Agricultural Water Management 18:149-158.

Cullum, R.F., M.A. Locke, and S.S. Knight. 2010. Effects of conservation reserve program on runoff and lake water quality in an oxbow lake watershed. Journal of International Environmental Application and Science 5:318-328.

Garnett, T. 2013. Conference on 'Future food and health' Symposium I: Sustainability and food security. Proceedings of the Nutrition Society 72:29-39.

Haggard, B.E., J.T. Scott, and S.D. Longing. 2013. Sestonic chlorophyll- $a$ shows hierarchical structure and thresholds with nutrients across the Red River basin, USA. Journal of Environmental Quality 42:437-445.

Helmers, M.J., X. Zhou, H. Asbjornsen, R. Kolka, M.D. Tomer, and R.M. Cruse. 2012. Sediment removal by prairie filter strips in row-cropped ephemeral watersheds. Journal of Environmental Quality 41:1531-1539.

King, K.W., P.C. Smiley, Jr., B.J. Baker, and N.R. Fausey. 2008. Validation of paired watersheds for assessing conservation practices in the Upper Big Walnut Creek watershed, Ohio. Journal of Soil and Water Conservation 63(6):380-395, doi:10.2489/jswc.63.6.380.

Kröger, R., M.M. Holland, M.T. Moore, and C.M. Cooper. 2007. Plant senescence:A mechanism for nutrient release in temperature agricultural wetlands. Environmental Pollution 146:114-119.

Kröger, R., M.T. Moore, J.L. Farris, and M. Gopalan. 2011. Evidence for the use of low-grade weirs in drainage ditches to improve nutrient reductions from agriculture. Water, Air, and Soil Pollution 221:223-234.

Lerch, R.N., C. Baffaut, N.R. Kitchen, and E.J. Sadler. 2015. Long-term agroecosystem research in the
Central Mississippi River Basin: Dissolved nitrogen and phosphorus transport in a high-runoff-potential watershed. Journal of Environmental Quality 44:44-57.

Li, H., F. Zhang, Y. Li, J. Wang, L. Zhang, L. Zhao, G. Cao, X. Zhao, and M. Du. 2016. Seasonal and inter-annual variations in $\mathrm{CO}_{2}$ fluxes over 10 years in an alpline shrubland on the Qinghai-Tibetan Plateau, China. Agricultural and Forest Meteorology 228-229:95-103.

Liu, X., X. Zhang, and M. Zhang. 2008. Major factors influencing the efficacy of vegetated buffers on sediment trapping: A review and analysis. Journal of Environmental Quality 37:1667-1674.

Lizotte, R.E., S.S. Knight, M.A. Locke, and R.L. Bingner. 2014. Influence of integrated watershed-scale agricultural conservation practices on lake water quality. Journal of Soil and Water Conservation 69(2):160-170, doi:10.2489/jswc.69.2.160.

Lizotte, R.E., L.M.W. Yasarer, M.A. Locke, R.L. Bingner, and S.S. Knight. 2017. Lake nutrient responses to integrated conservation practices in an agricultural watershed. Journal of Environmental Quality 46:330-338.

Madaras, J.S., and A.R. Jarrett. 2000. Spatial and temporal distribution of sediment concentration and particle size distribution in a field scale sedimentation basin. Transactions of the American Society of Agricultural Engineers 43:897-902.

Makarewicz, J.C., T.W. Lewis, I. Bosch, M.R. Noll, N. Herendeen, R.D. Simon, J. Zollweg, and A. Vodacek. 2009. The impact of agricultural best management practices on downstream systems: Soil loss and nutrient chemistry and flux to Conesus Lake, New York, USA. Journal of Great Lakes Research 35:23-36.

McLaughlin, R.A., S.A. Hayes, D.L. Clinton, M.S. McCaleb, and G.D. Jennings. 2009. Water quality improvements using modified sediment control systems on construction sites. Transactions of the American Society of Agricultural Engineers 52:1859-1867.

Meals, D.W., S.A. Dressing, and T.E. Davenport. 2010. Lag time in water quality response to best management practices: A review. Journal of Environmental Quality 39:85-96.

Moore, M.T., and R. Kröger. 2011. Evaluating plant species-specific contributions to nutrient mitigation in drainage ditch mesocosms. Water, Air, and Soil Pollution 217:445-454.

Moore, M.T., R. Kröger, M.A. Locke, R.F. Cullum, R.W. Steinriede, Jr., S. Testa III, R.E. Lizotte, Jr., C.T. Bryant, and C.M. Cooper. 2010. Nutrient mitigation capacity in Mississippi Delta, USA drainage ditches. Environmental Pollution 158:175-184.

Palmer-Felgate, E.J., R.J.G. Mortimer, M.D. Krom, H.P. Jarvie, R.J. Williams, R.E. Spraggs, and C.J. Stratford. 2011. Internal loading of phosphorus in a sedimentation pond of a treatment wetland: Effect of a phytoplankton crash. Science of the Total Environment 409:2222-2232.

Pierobon, E., G. Castaldelli, S. Mantovani, F. Vincenzi, and E.A. Fano. 2013. Nitrogen removal in vegetated and unvegetated drainage ditches impacted by diffuse and point sources pollution. CLEAN Soil Air Water 41(1):24-31.

Sherman-Morris, K., C.L. Wax, and M.E. Brown. 2012. Mississippi Weather and Climate, p. 202. Jackson, MS: University Press of Mississippi.
Smith, D.R., S.J. Livingston, B.W. Zuercher, M. Larose, G.C. Heathman, and C. Huang. 2008. Nutrient losses from row crop agriculture in Indiana. Journal of Soil and Water Conservation 63(6):396-409, doi:10.2489/ jswc.63.6.396.

Steel, R.G.D., J.H. Torrie, and D.A. Dickey. 1997. Principles and Procedures of Statistics: A Biometrical Approach, 3rd edition. New York, NY: McGraw-Hill.

Stevenson, R.J., B.J. Bennett, D.N. Jordan, and R.D. French. 2012. Phosphorus regulates stream injury by filamentous green algae, DO, and $\mathrm{pH}$ with thresholds in responses. Hydrobiologia 695:25-42.

Tomer, M.D., and M.A. Locke. 2011. The challenge of documenting water quality benefits of conservation practices: A review of USDA-ARS's conservation effects assessment project watershed studies. Water Science and Technology 64:300-310.

Tomer, M.D., T.B. Moorman, and G.C. Rossi. 2008. Assessment of the Iowa River's South Fork watershed: Part 1. Water quality. Journal of Soil and Water Conservation 63(6):360-370, doi:10.2489/ jswc.63.6.360.

Tomer, M.D., E.J. Sadler, R.E. Lizotte, R.B. Bryant, T.L. Potter, M.T. Moore, T.L. Veith, C. Baffaut, M.A. Locke, and M.R. Walbridge. 2014. A decade of conservation effects assessment of research by the USDA Agricultural Research Service: Progress overview and future outlook. Journal of Soil and Water Conservation 69(5):365-373, doi:10.2489/jswc.69.5.365.

Tyler, H.L., M.T. Moore, and M.A. Locke. 2012. Influence of three aquatic macrophytes on mitigation of nitrogen species from agricultural runoff. Water, Air, and Soil Pollution 223:3227-3236.

Verstraeten, G., and J. Poesen. 2001. Modelling the long-term sediment trap efficiency of small ponds. Hydrological Processes 15:2797-2819.

Yuan, Y., M.A. Locke, R.L. Bingner, and R.A. Rebich. 2013. Phosphorus losses from agricultural watersheds in the Mississippi Delta. Journal of Environmental Management 115:14-20.

Yuan, Y., M.A. Locke, and L.A. Gaston. 2009. Tillage effects on soil properties and spatial variability in two Mississippi Delta watersheds. Soil Science 174:385-394. 